\title{
Challenges and Prospects of the Halal Hotel Industry in Muslim-majority and Muslim-minority Countries: The Case of Malaysia and Thailand
}

\author{
Wanamina Waehama \\ Faculty of Management Sciences, Prince of Songkla University \\ Hat Yai, Songkhla 90110, Thailand \\ Email: wanamina.w@psu.ac.th \\ Md. Mahmudul Alam \\ School of Economics, Finance \& Banking, Universiti Utara Malaysia \\ 06010 UUM Sintok, Kedah, Malaysia \\ Email: rony000@gmail.com \\ Mahmood Hayeemad \\ Faculty of Management Sciences, Prince of Songkla University \\ Hat Yai, Songkhla 90110, Thailand \\ Waemamu Waehama \\ Faculty of Management Sciences, Prince of Songkla University \\ Hat Yai, Songkhla 90110, Thailand \\ * Corresponding author
}

\section{Citation Reference:}

Waehama, W., Alam, M,M., Hayeemad, M., \& Waehama, W. (2018). Challenges and Prospects of the Halal Hotel Industry in Muslim-majority and Muslim-minority Countries: The Case of Malaysia and Thailand. Journal of Halal Industry and Services, 1(1): a0000018. http://journals.hh-publisher.com/index.php/JHIS/article/view/10 


\title{
Challenges and Prospects of the Halal Hotel Industry in Muslim-majority and Muslim- minority Countries: The Case of Malaysia and Thailand
}

\begin{abstract}
The number of Muslim tourists has surged in recent years due to increased number of Muslim population with higher segment of better educated and more prosperous Muslim community. Although this is undoubtedly an opportunity for the hotel industry, the unique religious and cultural needs of Muslims pose some challenges for hoteliers. A response to this has been the development of halal hotels which offer food, accommodation and entertainment that is halal. While establishing halal hotels in Muslim-majority countries like Malaysia seems to be easier with the inherent good understanding of Islamic practices as well as support from the government, halal hotel industry could also give competitive advantage to Muslim-minority industry such as Thailand. It is therefore pertinent and timely to look into the challenges and prospects of halal hotel industry in Malaysia and Thailand. The comparative research framework must include a considerable number of hotels encompassing a variety of scales of operation from both countries to obtain reliable qualitative data. The findings could assist policymakers and relevant authorities in setting the way forward for the industry particularly by establishing relevant regulation and economic environment that support the industry.
\end{abstract}

Keywords: Halal Hotel, Thailand, Malaysia

\section{Introduction}

In recent years, numbers of Muslim tourists have increased and are expected to continue to do so in the future (Jurattanasan \& Jaroenwisan, 2014; Rahim, 2016). Muslims have different religious and cultural beliefs from non-Muslims; necessitating the creation of hotels to cater for their particular needs, often referred to as halal hotels (Kamarulzaman et al. 2012). Halal is an Arabic word that means permitted and lawful. This concept comes from the Quran and is normally used to describe objects and actions, those that are halal must meet all the principles of Islam which Muslims are expected to abide by.

The requirements of a halal hotel are particularly exacting; all aspects of the operation must be halal. Cuisine is one of the most obvious requirements; all food and beverages prepared in a halal hotel, without exception, must be halal. However, the requirements of halal hotels are not restricted to food preparation. A halal hotel must have designated prayer rooms, appropriate bathroom facilities, sex-segregated pools, and a number of other requirements to meet the needs of Muslim travellers. According to El-Gohary (2016), one reason Muslims disliked traveling abroad was the difficulty finding halal hotels.

\section{Literature Review}

Both Malaysia and Thailand have well-established tourist industries with continuous effort to expand into the new market of Muslim tourism (Razalli et al. 2013). Although there is a paucity of studies of challenges facing the halal industry in the two nations, some issues have been identified.

\section{Halal Hotel Industry in Malaysia}


Malaysia was the first of the two countries to have a halal tourist industry (Idris \& Abdul Wahab, 2015). Although it was comparatively easy for a halal tourist industry to establish in a majority-Muslim country where the requirements of Muslims are well-understood and wellestablished, there was the need to reassure their international Muslim guests that their services were indeed halal (Gabdrakhmanov et al. 2016). To this end the Malaysian government established the national accreditation body, JAKIM, which determines if a hotel meets halal requirements (Samori \& Rahman, 2015). According to Westeastinstitute (2018), 102 hotels in Malaysia have been accepted as halal by JAKIM.

Competition is one of the greatest factors influencing the halal hotel industry in Malaysia. With over 102 hotels accredited by JAKIM, and an even greater number of non-accredited hotels that attempt to offer halal services, Muslim tourists visiting Malaysia have many options to choose from (Battour \& Ismail, 2016). It is also difficult for halal hotels to find and keep staff. The hotel industry was historically unpopular in Malaysia (Mansouri, 2014). Although this is changing, even now the work is known to be seasonal and to have unusually exacting requirements, requiring the staff to be Muslim, knowledgeable in Islamic regulations as well as trained in hospitality or catering (Battour et al. 2013).

Two factors give good prospects for the future of the halal hotel industry in Malaysia. First although the industry has been built on international Muslim tourists, there are also great possibilities for the development of the domestic Muslim tourist industry, offering the possibility of doubling the source market for halal hotels (Zulkharnain \& Jamal, 2012). Second, the industry has the full support of the government. This is demonstrated by establishing facilities to teach hotel and catering courses to meet the expanding demand of the halal hotel industry (Mansouri, 2014), providing an regulatory and economic environment in which the halal hotel industry can thrive (Nursanty, 2013) and the formation of JAKIM (Samori \& Rahman, 2015).

\section{Halal Hotels in Thailand}

Although Thailand has a vibrant tourism industry, it was in a relatively poor position to set up a halal hotel industry. As a majority-Buddhist country, many of the religious requirements of Muslims were poorly understood or difficult to meet. The recognition that Muslim tourists were seeking halal accommodation led to the opening of the four-star Al Meroz hotel in 2016 (Mohsin et al. 2017). Four More halal hotels have opened since, although the country lacks a halal accreditation organization.

The single biggest issue facing the emerging halal hotel industry in Thailand is a shortage of staff. To adequately meet the standards of halal hotels, many staff must be Muslim (Oktadiana et al. 2016). Only 5\% of Thailand's population is Muslim, and finding members of this population trained in hospitality is often very difficult. Some halal hotels have had to seek employees from overseas, which increases their costs of operation.

Nevertheless, the potential for halal hotels in Thailand is great (Chandra, 2014). More than 650,000 Muslims visit the country per year (Razalli et al. 2012), a number that is believed to increase with the opening of halal hotels (Samori \& Rahman, 2015). Although at present there is no specific support for halal hotels from the Thai government, such support would not be difficult to derive from systems already in place to support tourism in general.

\section{Future work}


In order to better understand the challenges and prospect of halal hotel industries in Malaysia and Thailand, there is a need to perform comparative study between the countries focussing on the opportunities for growth of the industry. A considerable number of hotels using openended questions shall allow the results of the mathematical analysis to be elaborated upon, providing information and context that would otherwise be lacking.

The framework of this exploratory, comparative study is shown in Figure 1.

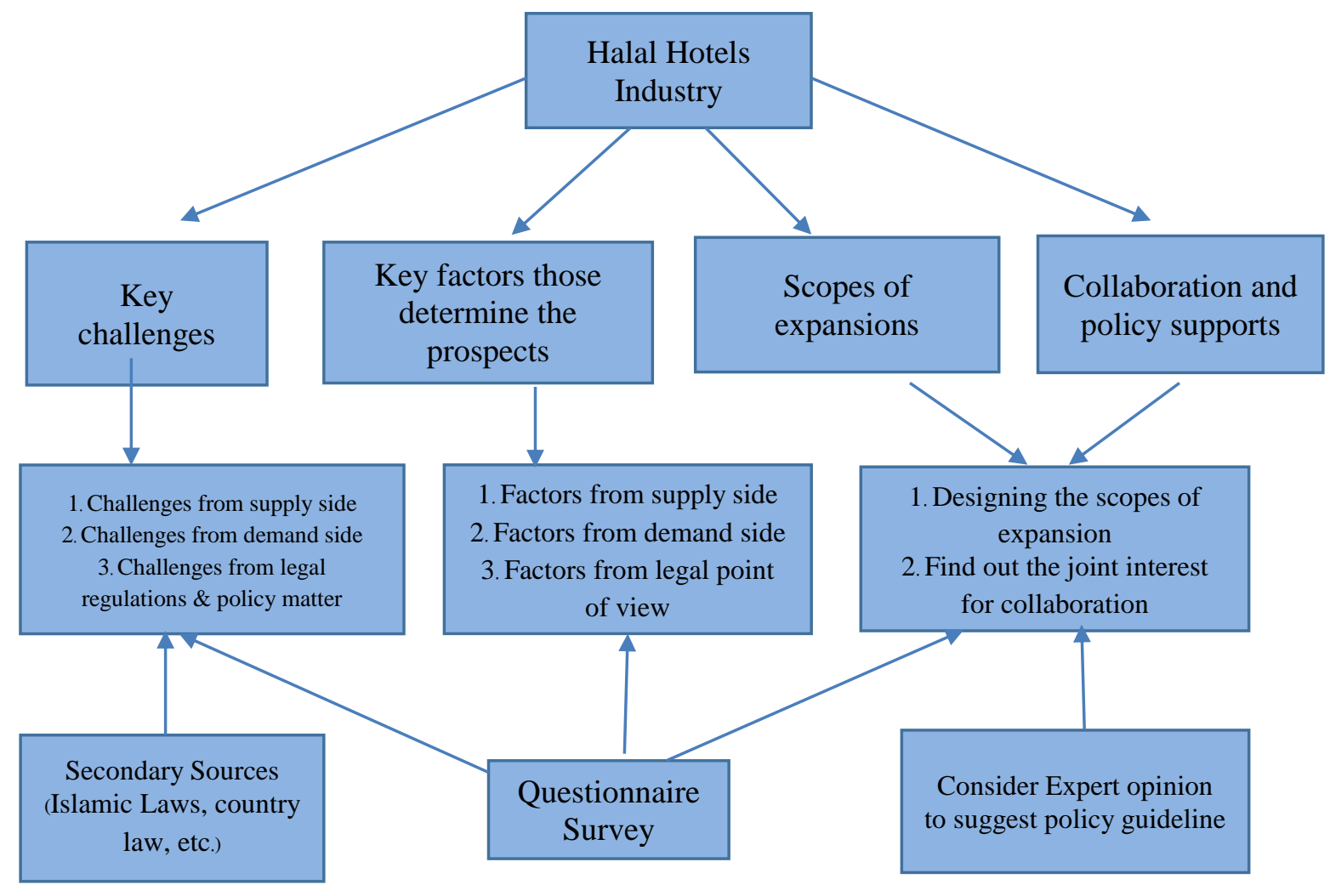

Figure 1: The proposed research framework of the study

\section{Conclusion}

This research framework could lead to important findings on the challenges and prospect of halal hotel industry in Muslim-majority and Muslim-minority countries. This could assist policymakers and relevant authorities in setting the way forward for the industry particularly by establishing relevant regulation and economic environment that support the industry.

\section{Acknowledgement}

We are grateful to the Halal Institute at Prince of Songkla University for generously funding this research, under the Research Code \# 20404.

\section{References}

Battour, M. M., Ismail, M. N., \& Battor, M. (2013). Toward a halal tourism market. Tourism Analysis, 15(4), 461-470. 
Battour, M., \& Ismail, M. N. (2016). Halal tourism: Concepts, practises, challenges and future. Tourism Management Perspectives, 19, 150-154.

Chandra, G. R. (2014). Halal Tourism: A New Gold Mine for Tourism. International Journal of Business Management \& Research, 4(6), 45-62. countries. Review of Integrative Business and Economics Research, 3, 39.

El-Gohary, H. (2016). Halal tourism, is it really Halal?. Tourism Management Perspectives, 19, 124-130.

Gabdrakhmanov, N. K., Biktimirov, N. M., Rozhko, M. V., \& Mardanshina, R. M. (2016). Features of Islamic Tourism. Academy of Marketing Studies Journal, 20, 45.

Idris, J., \& Abdul Wahab, N. (2015). The Competitive Advantages of Sharia-Compliant Hotel Concept in Malaysia: SWOT Analysis. Retrieved from: http://www.kuis.edu.my/icomm/2nd/download/IC\%20015.pdf

Jurattanasan, A., \& Jaroenwisan, K. (2014). The attribution of shariah compliant hotel in Muslim

Kamarulzaman, Y., Ghani, F. A., \& Madun, A. (2012). The acceptance of Islamic hotel concept in Malaysia: a conceptual paper. Retrieved from https://umexpert.um.edu.my/file/publication/00009698_87134.pdf.

Mansouri, S. (2014). Role of Halal tourism ideology in destination competitiveness: a study on selected hotels in Bangkok, Thailand. In International Conference on Law, Education and Humanities, Pattaya, Thailand.

Mohsin, A., Ramli, N., \& Alkhulayfi, B. A. (2017). Halal tourism: Emerging opportunities. Tourism Management Perspectives, 19, 137-143.

Mutum, D. S., Butt, M. M., \& Rashid, M. (Eds.), Advances in Islamic Finance, Marketing, and Management: An Asian Perspective, (pp. 271-307).

Nursanty, E. (2013). Halal Tourism, The New Product in Islamic Leisure Tourism and Architecture.

Oktadiana, H., Pearce, P. L., \& Chon, K. (2016). Muslim travellers' needs: What don't we know? Tourism Management Perspectives, 20, 124-130.

Rahim, N. (2016). Consumer Behaviour, Perception and Planning Towards Halal Marketing. In

Razalli, M. R., Abdullah, S., \& Yusoff, R. Z. (2012). Is Halal certification process "green". The Asian Journal of Technology Management, 5(1), 33-41.

Razalli, M. R., Yusoff, R. Z., \& Roslan, M. W. M. (2013). A framework of halal certification practices for hotel industry. Asian Social Science, 9(11), 316. Retrieved from: http://www.academia.edu/2218300/Halal_Tourism_The_New_Product_In_Islamic_L eisure Tourism_And_Architecture

Samori, Z., \& Rahman, F. A. (2015). Establishing shariah compliant hotels in Malaysia: Identifying opportunities, exploring challenges. West East Journal of Social Sciences, 2(2), 95-108.

Westeastinstitute.com (2018) Retrieved 2 March 2018, from https://www.westeastinstitute.com/wp-content/uploads/2013/07/Zakiah-Samori-FullPaper.pdf

Zulkharnain, A., \& Jamal, S. A. (2012). Muslim guest perception of value towards Syariah concept hotel. Current Issues in Hospitality and Tourism, 337-340. 